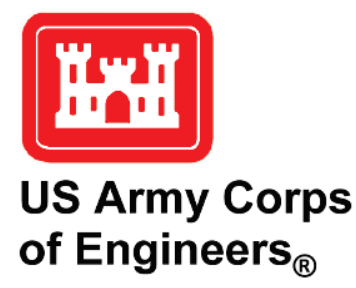

\title{
Overview of Historical Reservoir Flushing Events and Screening Guidance
}

by Travis A. Dahl and Marielys Ramos-Villanueva

PURPOSE: This Coastal and Hydraulics Engineering Technical Note (CHETN) provides an overview of the current state-of-the-practice screening criteria for reservoir sediment management actions, as well as a listing of historical reservoir flushing events and programs. This document also outlines the next steps in the Reservoir Flushing Research and Development Work Unit.

INTRODUCTION: Reservoirs are an important component of water resource systems around the world. Sediment trapped in reservoirs threatens their usefulness while also having the potential to cause problems upstream and downstream of the reservoir itself (Kondolf et al. 2014). The U.S. Army Corps of Engineers (USACE) maintains and operates more than 350 reservoirs within the United States, and many of those reservoirs are experiencing decreased project benefits due to sediment deposition (Pinson et al. 2016; USACE 2016). Existing and continued sediment deposition will result in a reduction of reservoir storage available for project uses such as flood control, water supply, hydropower, recreation, and environmental purposes (e.g., minimum flows). To achieve long-term sustainable performance of reservoirs, it is necessary to find and understand sediment management techniques that could be effective for each reservoir.

Flushing is one simple technique for managing sediment in reservoirs. In general, reservoir flushing involves opening low-level gates in a dam and allowing the water to remove sediment from the reservoir. There are two general cases of this technique. Pressure flushes are conducted for a short time, thereby limiting the drawdown of water in the reservoir while also restricting the affected area to a relatively small area immediately upstream from the gate. Drawdown flushes lower the water level in the reservoir, using both the increased flow of water and the increased water surface slope to erode large quantities of sediment throughout the reservoir. When a drawdown flush is timed to coincide with a large, sediment-laden inflow, it may be referred to as sluicing or drawdown routing (ICOLD 1999).

This CHETN provides a listing of reservoirs that have implemented reservoir flushing programs, describes the current state-of-the-practice screening criteria for successful reservoir flushes, and discusses the next steps required to improve guidance for reservoir flushing.

HISTORICAL RESERVOIR FLUSHING EVENTS: Flushing sediment through a reservoir is not a new technique. According to a review of the literature, there have been reports of sediment flushing as early as 1939 in the Zemo-Afchar Reservoir in the Former USSR (Chaudhry 2012). A full-drawdown flushing program apparently took place until 1955 removing approximately 1 million cubic meters of sediment per year.

A review of current literature identified 31 reservoirs around the world that have attempted sediment flushing (Table 1). At least nine of these reservoirs (Gmund, Hengshan, Honglingjin, 
Naodehai, Baira, Mangahao, Gebidem, Palagneda, and Santo Domingo) were capable of maintaining more than $50 \%$ of their original capacity through flushing, the criteria considered successful based on the screening guidance provided by Atkinson (1996).

\section{Table 1. Reservoirs where flushing has been attempted.}

\begin{tabular}{|c|c|c|c|}
\hline Reservoir & Location & $\begin{array}{l}\text { Dam } \\
\text { Completed }\end{array}$ & Source \\
\hline Gmund & Austria & 1945 & Rienossl and Schnelle 1982; Atkinson 1996 \\
\hline Gaunting & China & 1953 & Atkinson 1996 \\
\hline Heisonglin & China & 1959 & Atkinson 1996 \\
\hline Hengshan & China & 1966 & IRTCES 1985; Atkinson 1996 \\
\hline Honglingjin & China & & IRTCES 1985; Atkinson 1996 \\
\hline Nanqin & China & 1974 & Chen and Zhao 1992 \\
\hline Naodehai & China & 1942 & IRTCES 1985; Atkinson 1996 \\
\hline Sanmenxia & China & 1960 & Atkinson 1996 \\
\hline Shuicaozi & China & 1958 & Atkinson 1996 \\
\hline Cachí & Costa Rica & 1966 & $\begin{array}{l}\text { Jansson and Rodriguez (eds) 1992; Brandt and } \\
\text { Swenning 1999; Jansson and Erlingsson } 2000\end{array}$ \\
\hline Ouchi-Kurgan & Former USSR & 1961 & IRTCES 1985; Atkinson 1996 \\
\hline Zemo-Afchar & Former USSR & 1927 & Atkinson 1996 \\
\hline Genissiat & France & 1948 & Sumi 2008 \\
\hline Baira & India & 1981 & Jaggi and Kashyap 1984; Atkinson 1996 \\
\hline Ichari & India & 1975 & Atkinson 1996 \\
\hline Sefid-Rud & Iran & 1962 & $\begin{array}{l}\text { Amini and Fouladi 1985; Parhami 1986; Mahmood } \\
\text { and Mundial 1987; Atkinson } 1996\end{array}$ \\
\hline Dashidaira & Japan & 1985 & Sumi 2008 \\
\hline Unazuki & Japan & 2001 & Sumi 2008 \\
\hline Mangahao & New Zealand & 1924 & Jowett 1984; Atkinson, 1996 \\
\hline Warsak & Pakistan & 1960 & Mahmood and Mundial 1987 \\
\hline Barenburg & Switzerland & 1960 & Sumi 2008 \\
\hline Gebidem & Switzerland & 1968 & Dawans et al 1982; Atkinson, 1996 \\
\hline Innerferrera & Switzerland & 1961 & Sumi 2008 \\
\hline Palagneda & Switzerland & 1952 & $\begin{array}{l}\text { Swiss Nat. Committee on Large Dams 1982; } \\
\text { Atkinson, } 1996\end{array}$ \\
\hline Verbois & Switzerland & 1943 & Sumi 2008 \\
\hline Khashm-el-Gibra & Sudan & 1964 & Chaudhry 2012 \\
\hline Jensanpei & Taiwan & 1938 & Sumi 2008 \\
\hline Fall Creek & USA & & Gibson and Crain ${ }^{1}$ \\
\hline Guernsey & USA & 1927 & Mahmood and Mundial 1987 \\
\hline Spencer Dam & USA & 1927 & Boyd and Gibson, 2016 \\
\hline $\begin{array}{l}\text { Santo Domingo } \\
\text { Reservoir }\end{array}$ & Venezuela & 1974 & Krumdieck and Chamot, 1979; Atkinson, 1996 \\
\hline
\end{tabular}

EXISTING SCREENING GUIDANCE: To achieve long-term sustainable sediment management in a reservoir, at least as much sediment needs to be removed from the reservoir on an annual basis as is deposited. Kondolf et al. (2014) suggest that at least 300 years be considered

${ }^{1}$ Gibson, S., and J. Crain. In review. Modeling Sediment Concentrations during a Drawdown Reservoir Flush: Simulating the Fall Creek Operations with HEC-RAS. ERDC RSM Technical Note. Vicksburg, MS: U.S. Army Engineer Research and Development Center. 
for long-term sustainability, meaning that even small differences in the reservoir sediment balance can allow significant accumulation. Reservoir flushing can be a cost-effective means of removing that sediment, but it is not always practical. Flushing can seldom maintain all of the original reservoir capacity in perpetuity. In some cases, a drawdown flush may only move sediment from the upstream delta farther into the reservoir rather than routing it all the way past the dam. Atkinson (1996) defines a successful reservoir flushing program as one that maintains a long-term capacity ratio (LTCR) (sustainable capacity/original capacity) greater than 0.5 . There may be situations where a smaller LTCR is acceptable because flushing will extend the useful life of the reservoir or maintain sediment continuity with the downstream river system.

The primary screening criteria for successful flushing of reservoirs in current guidance are based on three factors: the total capacity of the reservoir (CAP), the mean annual runoff to the reservoir (MAR), and the mean annual inflow of sediment to the reservoir (MAS). The lower the ratios of $\mathrm{CAP} / \mathrm{MAR}$ and CAP/MAS, the more likely it is that flushing can be a successful method for maintaining reservoir capacity (Atkinson 1996; ICOLD 1999; Kondolf et al. 2014; Sumi 2008). ICOLD (1999) recommends using CAP/MAR $<0.1$ and CAP/MAS $<30$ as screening criteria for conditions favorable to sediment flushing and sluicing.

While these broad screening criteria provide an initial assessment of the feasibility of flushing, they do not guarantee success. One of the most important additional constraints is the presence of suitable, low-level outlet gates for use in flushing the reservoir. If these are not present, they would need to be retrofit, usually at significant expense. The typical grain size of sediments in the reservoir and the amount of time the sediment has been allowed to consolidate (i.e., the time between flushing events) will influence the effectiveness of a drawdown flush. Incomplete drawdowns, where the flow depth during the flush is not significantly less than the normal level of the impoundment, will limit the success of the flush. Atkinson (1996) recommends at least a $70 \%$ reduction in water level during the flush. Other factors that can significantly impact the viability of reservoir flushing include downstream environmental concerns, reliability of water supply and forecasts, operational rules, reservoir geometry, and frequency of flushing events.

The reservoir volume that can be maintained over the long-term through flushing can be estimated based on the slope of the former river channel, the size and elevation of the flushing gates, and an estimate of the side-slope stability of the drawn-down reservoir (Atkinson 1996). Given sufficient time with a free-flowing river condition in the reservoir, the drawdown flush should create a channel through the reservoir that is equal to the width of the gate openings and at the slope of the former river bed. The volume of this open channel can be estimated by treating it as a trapezoidal channel with the side slopes based on the properties of the sediment (e.g., grain size and consolidation time).

FUTURE WORK: More refined criteria would be beneficial to reservoir operators to determine whether drawdown flushes or sluicing can be a useful technique for reducing sedimentation at individual projects. USACE researchers are working to codify the impacts of sediment size and type, as well as reservoir geometry characteristics such as the length, width, depth, and slope. The researchers will also look for patterns and differences between reservoirs in arid environments and those with more reliable rainfall. 
Improvements in the ability of numerical models to simulate reservoir flushes will also be undertaken. This will include the ability to use operational rules for gate openings in the Adaptive Hydraulics (AdH) model, an adaptive finite-element model for one-, two- and three-dimensional flow and transport (ERDC CHL 2017). A significant factor in the effectiveness of reservoir flushing is the erosion and failure of side slopes in the drawn-down reservoir. Future work will need to look at how side slope erosion and failure occur and how to implement these processes in numerical models. The required algorithms and approaches include the parameters for failing the slopes and how to adjust the bank stations in one-dimensional models or the mesh in a multi-dimensional model.

It is likely that reservoir flushing efficiency can be improved through changes to operational rules. This includes determining how frequently to flush a given reservoir. In some cases, a sequence of drawdown and refill events may be more effective at mobilizing sediment. Mechanical disturbance of the reservoir sediment has been used to improve reservoir flushing in some locations. This could be done using heavy machinery or water-injection dredging. If the reservoir has not been flushed for several decades, initial dredging may be necessary before starting a routine of regular drawdown flushes. These management procedures will be explored during future phases of the Reservoir Flushing Research and Development Work Unit.

ADDITIONAL INFORMATION: This CHETN was prepared by Travis A. Dahl and Marielys Ramos-Villanueva, research hydraulic engineers at the U.S. Army Engineer Research and Development Center, Coastal and Hydraulics Laboratory. Questions about this CHETN can be addressed to Mr. Dahl (601-634-2371; Travis.A.Dahl@usace.army.mil).

This CHETN should be cited as follows:

Dahl, T. A., and M. Ramos-Villanueva. 2019. Overview of Historical Reservoir Flushing and Screening Guidance. ERDC/CHL CHETN-VII-21. Vicksburg, MS: U.S. Army Engineer Research and Development Center. http://dx.doi.org/10.21079/11681/33003.

\section{REFERENCES}

Amini, A., and C. Fouladi. 1985. "Sediment Flushing at the Sefidrud Reservoir." In Proceedings: Second International Workshop on Alluvial River Problems. Roorkee, India. New Delhi: Central Board of Irrigation and Power.

Atkinson, E. 1996. The Feasibility of Flushing Sediment from Reservoirs. Report OD 137. Wallingford, UK

Boyd, P. M., and S. Gibson. 2016. Applying 1D Sediment Models to Reservoir Flushing Studies: Measuring, Monitoring, and Modeling the Spencer Dam Sediment Flush with HEC-RAS. Vicksburg, MS: U.S. Army Engineer Research and Development Center.

Brandt, S. A., and J. Swenning. 1999. "Sedimentological and Geomorphological Effects of Reservoir Flushing: The Cachi Reservoir, Costa Rica, 1996.” Geografiska Annaler: Series A, Physical Geography 81(3): 391-407.

Chaudhry, M. A. 2012. "Worldwide Experience of Sediment Flushing through Reservoirs." Mehran University Research Journal of Engineering and Technology 31(3): 395-408.

Chen, J., and K. Zhao. 1992. "Sediment Management in Nanqin Reservoir." International Journal of Sediment Research 7(3): 71-84.

Dawans, P., J. Charpie, W. Giezendanner, and H. P. Rufenacht. 1982. "Le Degravement de la Retenue de Gebidem: Essais sur Modele et Experiences sur Prototype." In Transactions of the Fourteenth International Congress on Large Dams, Vol. 3. 
ICOLD. 1999. Dealing with Reservoir Sedimentation: Guidelines and Case Studies = Gestion de lálluvionnement des Retenues: Recommandations et Exemples. Vol. 115. Paris, France: Commission Internationale des Grand Barrages.

IRTCES. 1985. Lecture notes of the training course on reservoir sedimentation. International Research and Training Centre on Erosion and Sedimentation.

Jaggi, A. L., and B. R. Kashyap. 1984. "Desilting of Baira Reservoir of Baira Siul Project." Water and Energy International 41(4): 375-380.

Jansson, M. B., and U. Erlingsson. 2000. "Measurement and Quantification of a Sedimentation Budget for a Reservoir with Regular Flushing." Regulated Rivers: Research \& Management: An International Journal Devoted to River Research and Management 16(3): 279-306.

Jansson, M. B., and A. Rodríguez, eds. 1992. Sedimentological Studies in the Cachi Reservoir, Costa Rica: Sediment Inflow, Reservoir Sedimentation, and Effects of Flushing. UNGI Report No. 81. Department of Physical Geography, Uppsala University, Uppsala.

Jowett, I. 1984. "Sedimentation in New Zealand Hydroelectric Schemes." Water International 9(4): 172-176.

Kondolf, G. M., Y. X. Gao, G. W. Annandale, G. L. Morris, E. H. Jiang, J. H. Zhang, Y. Cao, P. Carling, K. Fu, Q. Guo, R. Hotchkiss, C. Peteuil, T. Sumi, H-W. Wang, Z. Wang, Z. Wei, B. Wu, C. Wu, and C. T. Yang. 2014. "Sustainable Sediment Management in Reservoirs and Regulated Rivers: Experiences from Five Continents." Earth's Future 2(5): 256-280. doi:10.1002/2013ef000184

Krumdieck, A., and P. Chamot. 1979. Sediment Flushing at the Santo Domingo Reservoir. Electrowatt Engineering Services Limited.

Mahmood, K., and B. Mundial. 1987. "Reservoir Sedimentation: Impact, Extent and Mitigation." In Technical Paper, Vol. 71. World Bank.

Parhami, F. 1986. "Sediment Control Methods in Sefid-Rud Reservoir Dam (Iran)." In Third International Symposium on River Sedimentation, Jackson, MS.

Pinson, A. O., B. Baker, P. Boyd, R. Grandpre, K. D. White, and M. Jonas. 2016. U.S. Army Corps of Engineers Reservoir Sedimentation in the Context of Climate Change. CWTS 2016-05. https://usace.contentdm.oclc.org/digital/collection/p266001coll1/id/5203/

Rienössl, K., and P. Schnelle. 1982. "Sedimentation of Small Reservoirs in the High Alps." In Fourteenth International Congress on Large Dams, Rio de Janeiro, Brazil, Vol. 3, 65-82).

Sumi, T. 2008. Evaluation of Efficiency of Reservoir Sediment Flushing in Kurobe River. Paper presented at the 4th International Conference on Scour and Erosion, Tokyo, Japan.

Swiss National Committee on Large Dams. 1982. General Paper 8. 14th Congress on Large Dams, ICOLD, Rio de Janeiro, vol. 3, 889-958.

U.S. Army Corps of Engineers (USACE). 2016. Status and Challenges for USACE Reservoirs. 2016-RES-01. https://www.iwr.usace.army.mil/Portals/70/docs/iwrreports/2016-RES-01.pdf

U.S. Army Engineer Research and Development Center, Coastal and Hydraulics Laboratory (ERDC CHL). 2017. Adaptive Hydraulics 2D Shallow Water (AdH-SW2D) User Manual (Version 4.6). Vicksburg, MS: U.S. Army Engineer Research and Development Center. https://chl.erdc.dren.mil/adh/documentation/AdH_Manual_Hydrodynamic-Version4.6.pdf

NOTE: The contents of this technical note are not to be used for advertising, publication, or promotional purposes. Citation of trade names does not constitute an official endorsement or approval of the use of such products. 